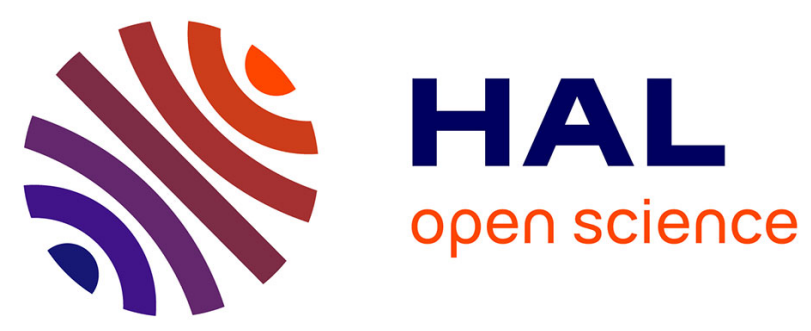

\title{
Macroscopic Analysis of Interfacial properties of Flax/PLLA biocomposites
}

\author{
Antoine Le Duigou, Peter Davies, Christophe Baley
}

\section{To cite this version:}

Antoine Le Duigou, Peter Davies, Christophe Baley. Macroscopic Analysis of Interfacial properties of Flax/PLLA biocomposites. Composites Science and Technology, 2010, 70 (11), pp.1612. 10.1016/j.compscitech.2010.06.001 . hal-00666484

\section{HAL Id: hal-00666484 https://hal.science/hal-00666484}

Submitted on 5 Feb 2012

HAL is a multi-disciplinary open access archive for the deposit and dissemination of scientific research documents, whether they are published or not. The documents may come from teaching and research institutions in France or abroad, or from public or private research centers.
L'archive ouverte pluridisciplinaire HAL, est destinée au dépôt et à la diffusion de documents scientifiques de niveau recherche, publiés ou non, émanant des établissements d'enseignement et de recherche français ou étrangers, des laboratoires publics ou privés. 


\section{Accepted Manuscript}

Macroscopic Analysis of Interfacial properties of Flax/PLLA biocomposites

Antoine Le Duigou, Peter Davies, Christophe Baley

PII:

S0266-3538(10)00227-7

DOI:

10.1016/j.compscitech.2010.06.001

Reference:

CSTE 4736

To appear in:

Composites Science and Technology

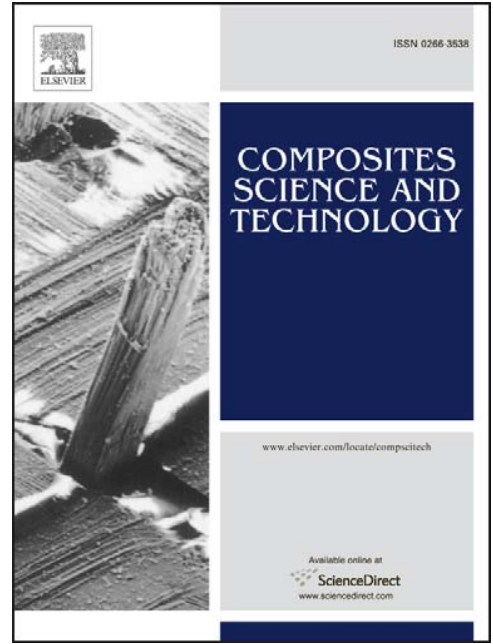

Received Date:

19 December 2009

Revised Date:

31 May 2010

Accepted Date:

2 June 2010

Please cite this article as: Le Duigou, A., Davies, P., Baley, C., Macroscopic Analysis of Interfacial properties of Flax/PLLA biocomposites, Composites Science and Technology (2010), doi: 10.1016/j.compscitech.2010.06.001

This is a PDF file of an unedited manuscript that has been accepted for publication. As a service to our customers we are providing this early version of the manuscript. The manuscript will undergo copyediting, typesetting, and review of the resulting proof before it is published in its final form. Please note that during the production process errors may be discovered which could affect the content, and all legal disclaimers that apply to the journal pertain. 


\title{
Macroscopic Analysis of Interfacial properties of Flax/PLLA biocomposites
}

\author{
Antoine Le Duigou ${ }^{1}$, Peter Davies ${ }^{2 *}$, Christophe Baley ${ }^{1}$ \\ 1 : LIMATB (Laboratoire d'Ingénierie des Matériaux de Bretagne) \\ Université de Bretagne Sud \\ - F - 56321 Lorient CEDEX \\ e-mails : antoine.le-duigou@univ-ubs.fr, christophe.baley@univ-ubs.fr \\ 2 : IFREMER, Brest Centre, Materials and Structures group \\ - F - 29280 Plouzané CEDEX \\ e-mail : peter.davies@ifremer.fr
}

\begin{abstract}
:
This study presents results from a study of the mechanical behaviour of flax reinforced Poly(L-Lactic Acid) (PLLA) under in-plane shear and mode I interlaminar fracture testing. Slow cooling of the unreinforced polymer has been shown to develop crystalline structure, causing improvement in matrix strength and modulus but a drop in toughness. The in-plane shear properties of the composite also drop for the slowest cooling rate, the best combination of in-plane shear performance and delamination resistance is noted for an intermediate cooling rate, $\left(15.5^{\circ} \mathrm{C} / \mathrm{min}\right)$. The values of $\mathrm{G}_{\mathrm{Ic}}$ obtained at this cooling rate are higher than those for equivalent glass/polyester composites. These macro-scale results have been correlated with microdroplet interface debonding and matrix characterization measurements from a previous study. The composite performance is dominated by the matrix rather than the interface.
\end{abstract}

Keywords : A. Fibres, A. Polymer matrix composites (PMCs), B. Interface, B. Interfacial strength, B. Delamination

*Corresponding author.

Tel.: 003329822 4777, Fax.: 003329822 4535, Email address : peter.davies@ifremer.fr 


\section{Introduction}

The development of composite materials for large scale industrial applications, such as those in which glass reinforced polyester is currently employed, raises a number of environmental questions, particularly regarding end-of-life management. An increasing demand for materials which respect the environment has encouraged research into alternatives which are not based on fossil fuels and have a low global warming impact. One solution is to develop biocomposites such as flax fibre reinforced Poly(L-Lactic Acid) (PLLA). This type of material is recyclable [1] and bio-degradable by composting. In addition, the analysis of environmental impacts, evaluated from raw material extraction through to end of life, has shown that compared to glass/polyester composites their non-renewable energy consumption is divided by two. Different impacts such as global warming are also significantly reduced, though a transfer of pollution occurs towards eutrophication [2]. The quasi static tensile modulus values of biocomposites are satisfactory [1,3] but their failure stresses are lower than those of glass/polyester composites. At the micro-mechanics scale Le Duigou et al [4], using a micro-droplet test to measure Interfacial Shear Strength on flax/PLLA, showed good interface properties, comparable to those of a glass/polyester combination. The strength of the flax/PLLA interface is influenced by the morphology of the semi-crystalline PLLA matrix and by residual thermal stresses induced by thermal treatments [4].

However, in order to study the influence of interface behaviour on the mechanical properties of laminated composites a change of scale is necessary. A certain number of mechanical tests are often used to evaluate the macroscopic interface strength of composites [5]. Among these are transverse tensile, in-plane shear by tension on $\mathrm{a} \pm 45^{\circ}$ laminate, short beam interlaminar shear, and interlaminar fracture tests. Few of these have been applied to biocomposites. Baley et al. [6] measured transverse tensile properties of flax/polyester composites. Their transverse strength was similar to that of glass/polyester composites (respectively $13 \pm 0.6 \mathrm{MPa}$ compared to $15 \pm 2.5 \mathrm{MPa}$ ). Rohmany et al [7] used the tensile test on $\pm 45^{\circ}$ Materbi/flax biocomposite laminates. However, they presented their results in terms of tensile rather than in-plane shear properties as the transverse strain was not measured. There is very little data available on either interlaminar or intralaminar shear strength of biocomposites. Concerning interlaminar fracture, mode I tests on glass mat/PLLA biocomposite indicated a low $\mathrm{G}_{\mathrm{Ic}}$ value of $39 \pm 8 \mathrm{~J} / \mathrm{m}^{2}$ [8]. For comparison, the mode $\mathrm{I}$ fracture toughness $G_{\text {Ic }}$ of a unidirectional glass reinforced Polyester is around $90 \mathrm{~J} / \mathrm{m}^{2}$ [9]. Davies et al [10] and Perrin et al. [11] have shown how the microstructure of a semi- 
crystalline polymer matrix affects the delamination resistance of glass/PP composites.

According to the cooling rate after moulding the $\mathrm{G}_{\mathrm{Ic}}$ value for the composite varies from 220 $\mathrm{J} / \mathrm{m}^{2}$ to $1270 \mathrm{~J} / \mathrm{m}^{2}$. Faster cooling resulted in improved fracture energies. Herrera-Franco et al [5] compared fibre-matrix adhesion measurements for carbon/epoxy with and without a fibre sizing, both at the micro scale (microdroplet debonding, fragmentation...) and the macro scale (tension $\pm 45^{\circ}$, Iosipescu, short beam shear...). Their study indicated similar trends for the influence of sizing at the two scales. Nevertheless some differences were seen, in particular due to the assumptions used in the calculations [5].

The aim of the present study is to evaluate the behaviour of flax/PLLA under in-plane shear and mode I delamination as a function of the parameters which influence fibre/matrix adhesion; these were previously shown in [4] to be the degree of crystallinity, the morphology of the matrix, and residual stresses. A comparison with results from the previous study, performed on the same fibres and matrix, will be made.

\section{Materials and methods}

\subsection{Specimen manufacture}

Specimens for in-plane shear were prepared according to ASTM D3518 [12] with PLLA reinforced by $\left( \pm 45^{\circ}\right)$ flax layers. Fibre weight content is around $30 \%$. The biopolymer is a thermoplastic Poly(L-lactic acid) or PLLA reference L9000 from Biomer®. The fibres were supplied, in the form of layers of two unidirectional tapes of untwisted yarns in a $0 / 90^{\circ}$ configuration, stitched together with cotton thread, by C.R.S.T (France) with an areal weight of $500 \mathrm{~g} / \mathrm{m}^{2}$. The fibres were grown in France and had been dew retted before stripping and combing. The shear test standard requires a [45/-45] $]_{\mathrm{ns}}$ stacking sequence with $2<\mathrm{n}<4$, and at least 8 reinforcement layers to limit tension-flexion coupling [13] and increase the interlaminar area. Specimens were rectangular with the following dimensions : $(25 \times 160 \times 6.5)$ $\mathrm{mm}^{3}$. They were prepared using the cycle shown in figure 1 . Four conditions were examined; three different cooling cycles were applied, as shown in figure 2, plus an anneal below the glass transition temperature $\left(\mathrm{T}_{\mathrm{g}}\right)$. Cooling rates were measured by insertion of thermocouples at mid-thickness of the samples. Figure 2 shows measured values, with an almost linear cooling rate for slow cooling (A), the difference between the set moulding machine temperature and the specimen is small. At faster cooling rates the measured temperature is hyperbolic with a rapid drop to around $100^{\circ} \mathrm{C}$ followed by a slower drop to room temperature. 
This shape can be explained by the thermal inertia of the material. The cooling rates presented subsequently are estimated using the slopes of the curves over the range of temperatures in which the polymer morphology and the residual stresses are strongly influenced by cooling rate. For semi-crystalline samples, this range is between $T_{\max }$ and melting temperature $T_{f}$. For the amorphous samples it is between $T_{\max }$ and $T_{g}$. The values of these temperatures were measured initially using DSC (Differential Scanning Calorimetry).

These three cooling rates were applied in order to obtain different morphologies in the PLLA matrix. An anneal for $72 \mathrm{~h}$ below $\mathrm{T}_{\mathrm{g}}$ at $50^{\circ} \mathrm{C}$ enables residual stresses, generated by rapid cooling (quench in water) to be released without developing crystalline structure. The annealing time is determined using DSC. An endothermic peak appears at $\mathrm{T}_{\mathrm{g}}$ corresponding to the delayed reorganisation necessary to reach equilibrium.

The procedure to produce specimens for delamination resistance tests was similar to that described above, but with a shorter time at $190^{\circ} \mathrm{C}$ (Fig. 1) as the thickness is less $(4 \mathrm{~mm}$ compared to $6.5 \mathrm{~mm}$ ). The fibre content is the same, but here the biocomposite tested is reinforced by flax in the form of mat. The ISO 15024 [14] standard is applied, although it is primarily intended for testing delamination of unidirectionally reinforced composites, The flax mat is produced using a paper-making route. This results in a quasi-isotropic inplane fibre distribution which is interesting as it minimizes the weaknesses of natural fibres, their poor transverse and shear properties [15]. The mat also allows fibres with $9 \pm 1 \mathrm{~mm}$ length and a high aspect ratio $(\mathrm{L} / \mathrm{d} \approx 470)$ to be used, as fibre bundles are separated during the mat production process. The mats used here have an areal weight around $150 \mathrm{~g} / \mathrm{m}^{2}$ and have not undergone any chemical or physical surface treatment.

A Teflon film 20 microns thick is inserted at mid-thickness during manufacture to provide a starter crack. This is slightly thicker than the ISO 15024 [14] standard recommends $(<13$ microns). It is also not possible to measure $\mathrm{G}_{\mathrm{Ic}}$ values on these mat reinforced composites directly as their flexural properties are too low, so they are bonded to machined aluminium

reinforcements of dimensions $(200 \times 20 \times 4) \mathrm{mm}^{3}$ (Fig. 4). Ten specimens with different initial starter crack lengths $\mathrm{a}_{0}\left(40<\mathrm{a}_{0}<75 \mathrm{~mm}\right)$ were tested for each material.

\subsection{Mechanical tests}

\subsubsection{Tension $\pm 45^{\circ}$ : In-plane shear}

The in-plane shear specimens underwent similar thermal treatments to those applied to microdroplets previously [4] in order to be able to compare results. This tensile test on \pm 
$45^{\circ}$ laminates was chosen as it is sensitive to interface and matrix properties. Tests were performed according to ASTM D 3518 [12] on an Instron 8803 machine with a 50kN load cell, at a crosshead displacement rate of $2 \mathrm{~mm} / \mathrm{min}$. An MTS biaxial extensometer was used to measure longitudinal and transverse strains. This test provides shear stress $\tau_{12}$, shear strain $\gamma_{12}$ and shear modulus $\mathrm{G}_{12}$ values. Modulus $G_{12}$ was determined from the slope of the plot of shear stress Eq. (1) versus shear strain (equation 2) in the range ${ }_{12}$ range between 0 and $0.2 \%$.

$$
\tau_{12}=\frac{\sigma_{\mathrm{x}}}{2}
$$

where $\sigma_{\mathrm{x}}$ is the applied stress.

$$
\gamma_{12}=\left(\varepsilon_{x}^{0}-\varepsilon_{y}^{0}\right)
$$

Particular attention is required for stress values. A $1^{\circ}$ fibre rotation occurs for an axial strain of $2 \%$. According to the ASTM D3518 standard [12] if the shear strain is below 5\% the shear stress can be taken as the maximum value $\left(\sigma_{\mathrm{x}}=\sigma_{\max }\right)$, if not then the value at $=5 \%$ should be used and $\sigma_{\mathrm{x}}=\sigma_{=5 \%}$.

The limitations of the test are :

- A lack of accuracy in strain measurements due to material heterogeneity, with resin rich regions and stitching fibres.

- The shear stress state in the sample, which is not pure due to interlaminar shear and normal stresses [5].

- Fibre angle variability.

For the unreinforced matrix shear properties were calculated from tensile data assuming isotropic behaviour and a Von Mises criterion:

$G_{12}=\frac{E}{2(1+v)}$

$\tau_{12}=\frac{\sigma}{\sqrt{3}}$

The shear modulus $\mathrm{G}_{12}$ of a unidirectional composite may be estimated using the Halpin-Tsai equation [16] : 
$\frac{M}{M_{m}}=\frac{1+\xi \cdot \eta \cdot V_{f}}{1-\eta \cdot V_{f}}$

with

$\eta=\frac{\frac{M_{f}}{M_{m}}-1}{\frac{M_{f}}{M_{m}}+\xi}$

where $M=G_{L T}, M_{f}=G_{f}, M_{m}=G_{m} . m, f, L$ and $T$ indicate respectively the matrix, the fibre, and longitudinal and transverse properties. $\mathrm{V}_{\mathrm{f}}$ is the fibre volume fraction and $\xi$ a form factor which depends on the geometry of the fibre and loading type. $\xi=1$ here [16] with an L/d ratio of 470. The value of $\mathrm{G}_{\mathrm{fT}}$ is taken to be $3315 \mathrm{MPa}$, based on previous work by Baley et al on flax fibres [17]. It should be emphasized that the aim here is not to develop a micromechanics analysis, but simply to compare measured shear modulus values with those estimated using a simple expression which is widely-used on traditional glass and carbon reinforced materials.

\subsubsection{Mode I delamination}

The mode I delamination test, which enables the critical strain energy release rate $G_{1 c}$ to be measured, was chosen as it is also sensitive to interface and matrix properties. The Double Cantilever Beam (DCB) specimen (Fig. 3a) allows the energy required to initiate and propagate a crack from a thin film defect to be quantified. Here only the initiation values will be discussed, as described by the ISO 15024 standard [14], subsequent propagation values are controversial as the crack can wander through the mat thickness and multiple cracks may be generated $[18,19]$. Various techniques can be used to detect crack initiation, including the non-linearity of the load-displacement plot, acoustic emission, strain gauge recording slope changes, and visual or camera observation [20]. Here, observation using a Sony digital camera was employed, linked to an in-house data acquisition system which also records images, together with the load (F) and opening displacement ( ) from an MTS RT 1000 test machine, at $2 \mathrm{~Hz}$. (Fig. 3b). White paint on the specimen edge helps to reveal the crack (Fig. 3c). Loading rate was $2 \mathrm{~mm} /$ minute.

The value of $\mathrm{G}_{\mathrm{Ic}}$ corresponding to initiation was determined using a compliance calibration approach:

$G_{1 c}=\frac{F^{2}}{2 b} \frac{d C}{d a}$ 
where $\mathrm{C}$ is the compliance:

$$
\mathrm{C}=\frac{\delta}{\mathrm{F}}
$$

The compliance calibration used here is that proposed by Berry [21]:

$$
\mathrm{C}=\mathrm{ka}^{\mathrm{n}}
$$

where the value of $\mathrm{n}$ is determined experimentally by plotting $\ln (\mathrm{C})$ versus $\ln (\mathrm{a}) . \mathrm{k}$ is a constant. Here different initial crack lengths were used to establish this relationship.

The value of strain energy release rate $G_{I}$ can then be obtained as :

$$
\mathrm{G}_{1}=\frac{\mathrm{nF} \delta}{2 \mathrm{ba}}
$$

where $b$ is the specimen width. A critical $G_{I c}$ initiation value is then calculated from the load value at observed initiation.

\subsubsection{Matrix fracture toughness}

A notched three point flexure test was used to determine the matrix fracture toughness [22] (ISO 13586). The specimens were rectangular, of thickness, B (4mm), and width $\mathrm{W}$ with an initial crack length a. The specimens respect the size imposed by the standard:

$4 \mathrm{~B}>\mathrm{W}>2 \mathrm{~B}, \mathrm{~L}=4 \mathrm{~W}, 0.45<\mathrm{a} / \mathrm{W}<0.55$, and all dimensions $>2.5\left(\mathrm{~K}_{\mathrm{c}} / \sigma_{\mathrm{y}}\right)^{2}$.

The notch is introduced by a saw cut followed by tapping a new razor blade to precrack it.

This is not a trivial operation with a brittle polymer and there is a tendency to produce shorter cracks which results in an overestimation of $\mathrm{K}_{1 \mathrm{c}}$ and $\mathrm{G}_{1 \mathrm{c}}$.

Loading rate is $10 \mathrm{~mm} / \mathrm{min}$ to limit crack tip blunting. A critical stress intensity factor $\mathrm{K}_{1 \mathrm{c}}$ is calculated as [23]:

$K_{1 c}=\frac{3 L F_{\max }}{B W^{2}}\left(\frac{\pi W}{2}\right)^{0.5}$

where $\mathrm{F}_{\max }$ is the maximum force, $\mathrm{L}$ the distance between supports, $\mathrm{B}$ and $\mathrm{W}$ are respectively the width and thickness of the specimens. A fracture energy $\mathrm{G}_{\mathrm{Ic}}$ can be determined from $\mathrm{K}_{\mathrm{Ic}}$ using the expression :

$G_{1 c}=\frac{K_{1 C}}{E}\left(1-v^{2}\right)$ 
with $E$ Young's modulus and $v$ the Poisson's ratio.

Samples were made using the same procedure as for the composites, with the same thermal treatments.

\subsubsection{DSC}

Thermal analysis was performed using a Mettler Toledo DSC on samples weighing around $10 \mathrm{mg}$. These were first heated at $190^{\circ} \mathrm{C}$ for 3 minutes to measure melting enthalpies. Crystallization enthalpies were also measured during heating, by integrating over a fixed temperature range. The degree of crystallinity $\left(\chi_{c}\right)$ was estimated using Eq. (13): $\chi_{\mathrm{c}}=\left(\Delta \mathrm{H}_{\mathrm{m}}-\Delta \mathrm{H}_{\mathrm{c}}\right) / \Delta \mathrm{H}_{100 \%}$ with $\Delta \mathrm{H}_{100 \%}$ crystalline $=93.7 \mathrm{~J} / \mathrm{g}[24]$.

\subsubsection{Scanning Electron Microscopy (SEM)}

Fracture surfaces, coated with a thin gold layer, were examined in a Jeol JSM 6460LV SEM.

\subsubsection{Polarization microscopy}

As PLLA is a semi-crystalline polymer, crystallization can occur during cooling. Thin films were prepared, by hot compression, and observed under an optical polarized light microscope on a Mettler Toledo heated stage in order to study the morphology at different cooling rates.

\section{Results and discussion}

\subsection{PLLA matrix properties}

\subsubsection{Thermal properties}

Table 1 shows how different cooling rates and annealing affect the unreinforced matrix structure. Quenching at $93^{\circ} \mathrm{C} / \mathrm{min}$ results in an amorphous PLLA structure, (Table 1), no crystalline structure (spherulites) is visible (Fig. 4a). Annealing at $50^{\circ} \mathrm{C}$ (below the $\mathrm{Tg}$ of $65^{\circ} \mathrm{C}$ ) does not result in a recrystallization. Slower cooling results in an increase in degree of crystallinity, reaching 33\%. This is in agreement with previous studies [25] on similar materials. It is interesting to note, however, that the degree of crystallinity is lower than that 
found in a previous study of microdroplets of the same polymer [4]. The difference is due to slightly different cooling rates and, above all, to the difference in specimen volume

$\left(\mathrm{V}_{\text {microdroplet }} \approx 8.10^{-13} \mathrm{~cm}^{3}\right.$ compared to $\left.\mathrm{V}_{\text {bulk sample }} \approx 10 \mathrm{~cm}^{3}\right)$. Fig. $4 \mathrm{~b}$ and $\mathrm{c}$ show the appearance of spherulites whose size increases at slower cooling rate $\left(1.5^{\circ} \mathrm{C} / \mathrm{min}\right)$. Some inter-spherulitic defects are visible, particularly for samples cooled at $1.5^{\circ} \mathrm{C} / \mathrm{min}$. These may result in poor bonding between the spherulites [10].

\subsubsection{Thermomechanical Properties}

Table 2 presents the mean measured tensile properties and their standard deviations and estimated shear properties of the PLLA matrix for the different thermal conditions. The tensile data were presented previously [4]. Slow cooling results in improved modulus and strength, due to higher crystallinity. However, failure strain is reduced. These properties are very similar to those of orthophthalic polyester resins [9] which are commonly used in glass fibre reinforced composites. The low failure strain of PLLA, whatever the cooling cycle, is a weak point and alternative grades with higher failure strains are being evaluated. Faster cooling $\left(15.5\right.$ et $\left.93{ }^{\circ} \mathrm{C} / \mathrm{min}\right)$ results in a small reduction in PLLA properties.

\subsubsection{Fracture toughness}

Table 3 shows mean critical stress intensity $\left(\mathrm{K}_{\mathrm{Ic}}\right)$, strain energy release rate $\left(\mathrm{G}_{\mathrm{Ic}}\right)$ values and their standard deviations for the PLLA polymer for the different conditions. For the slowest cooling rate $\left(1.5^{\circ} \mathrm{C} / \mathrm{min}\right), \mathrm{K}_{1 \mathrm{c}}$ and $\mathrm{G}_{1 \mathrm{c}}$ are low, similar to values respectively measured on orthophthalic $\left(\mathrm{K}_{1 \mathrm{c}}=0.419\right)$ [26] and isophthalic polyester resins $\left(\mathrm{K}_{\mathrm{Ic}}=0.45 \mathrm{MPa} \cdot \mathrm{m}^{0.5}\right)$ [26]. The large spherulitic microstructure and in particular the defects between spherulites (Fig. $4 c)$, provide an easier path for crack propagation. Fracture surfaces of specimens cooled at $1.5^{\circ} \mathrm{C} / \mathrm{min}$ (Fig. 5a) confirm this interspherulitic failure mode. Increasing cooling rate results in a significant increase in $\mathrm{K}_{1 \mathrm{c}}$ and $\mathrm{G}_{1 \mathrm{c}}$ for PLLA with values similar to those of some epoxy resins (e.g. $\mathrm{K}_{1 \mathrm{c}}=1.125 \mathrm{MPa} \cdot \mathrm{m}^{0.5}$ [26]). The fracture surface for the specimen cooled at $15.5^{\circ} \mathrm{C} / \mathrm{min}$ is completely different to that of the slower cooled sample (Fig. 5b), plastic deformation is apparent. Quenching reduces $\mathrm{K}_{1 \mathrm{c}}$ and $\mathrm{G}_{1 \mathrm{c}}$ slightly, annealing results in a small increase but the differences are small compared to scatter in results. The mechanical properties of the PLLA polymer are controlled by its microstructure in a similar way to those of more conventional polymers. 


\subsection{Composite in-plane shear}

Fig. 6 shows in-plane shear stress-strain plots from tensile tests on $\pm 45^{\circ}$ laminates of flax/PLLA biocomposite for different thermal conditions. The results are detailed in Table 4. The shear modulus $\mathrm{G}_{12}$ of the biocomposites is higher than that of the matrix but shear strength is lower (Table 4). The slow-cooled composite shows extensive surface cracking even before testing (Fig. 7a). There is a difference in thermal expansion coefficients of fibre and matrix (for flax fibre $\alpha_{\mathrm{fL}}=-1.10^{6} /{ }^{\circ} \mathrm{C}$ [27] and for PLLA matrix $\alpha_{\mathrm{m}}=78,5.10^{6} /{ }^{\circ} \mathrm{C}$ [4]) but the fibres also limit crystallization shrinkage during spherulite formation. These cracks will

limit the load-bearing capacity of the composites but values are still superior to the values for flax/polyester and glass/polyester composites with the same fibre content, $\mathrm{V}_{\mathrm{f}} 32 \%$, tested previously, $12=20.5 \pm 0.8$ and $20.1 \pm 1.3 \mathrm{MPa}$ respectively [28].

Composites cooled more quickly do not develop these cracks (Fig. 7b). Fig. 8a shows a fracture surface of a specimen cooled at $1.5^{\circ} \mathrm{C} / \mathrm{min}$., some interfacial debonding is apparent, with little plastic deformation. As for the PLLA alone the best properties correspond to the intermediate cooling rate $\left(15.5^{\circ} \mathrm{C} / \mathrm{min}\right)$. Very fast cooling $\left(93^{\circ} \mathrm{C} / \mathrm{min}\right)$ results in lower properties due to lower crystallinity. As shown in Figures $8 \mathrm{~b}$ and $8 \mathrm{c}$, fracture surfaces of fast cooled specimens indicate interfacial debonding, those of materials cooled at $15.5^{\circ} \mathrm{C} / \mathrm{min}$ reveal more matrix attached to fibres.

The annealing step has little influence on the behaviour of these biocomposites in shear. The sample size and the annealing time (72h) do not allow significant relaxation [29].

The shear modulus can also be estimated using Eq. (5) and (6). Results are shown in Table 5. The simple model gives a reasonable first estimation of in-plane modulus, overestimating the fast cooled sample values, possibly due to internal stress effects as the annealed material value is closer, and underestimating for the slow cooled specimens.

\subsection{Mode I delamination}

Mode I delamination tests were performed on flax mat reinforced PLLA. Fig. 9 shows examples of the load-displacement plots for the four sets of materials. Slow cooling $\left(1.5^{\circ} \mathrm{C} / \mathrm{min}\right)$ results in lower maximum force and force at non-linearity. The insert in Figure 9 shows all measured initial compliance values versus starter crack length (in meters) on a log- 
log plot. An n-value (slope) was determined for each set of samples and used to calculate $\mathrm{G}_{\mathrm{Ic}}$ with Eq.(9).Values of $\mathrm{n}$ were all in the range from 2.1 to 2.6. Table 6 summarizes the results. These values are calculated using the load corresponding to initiation observed visually. The use of the digital camera allows this point to be clearly defined. The results show that apart from the slowest cooled material all these flax/PLLA biocomposites have higher delamination resistance than glass mat reinforced polyester $\left(\sim 100 \mathrm{~J} / \mathrm{m}^{2}\right)[20]$, though this comparison should be made with caution as test conditions are not strictly identical (slightly thicker insert here). Concerning the influence of thermal treatments a similar tendency is observed to that noted by Davies et al. [10] and Perrin et al. [11] for UD glass/PP composites cooled at different rates. This can be explained by the reduction in fracture toughness of the slow cooled matrix (Table 2) due to development of crystallinity. The influence of high processing temperature on fibre properties may also play a role [30], this has not been quantified here. Fig. 10a shows mode I fracture surfaces for a slow-cooled specimen. Two mechanisms are apparent. First, residual matrix on the fibre suggests that reasonable fibrematrix adhesion is possible. Previous work suggested there may be a trans-crystalline phase in this region, though this was not observed [4]. Second, in the right hand photo some traces of fibres can be noted. These are much less marked than for the faster cooling (Fig. 10b, 10c) and show less development of ductile behaviour in the matrix [31]. As for the in-plane shear tests the best results correspond to intermediate cooling rate $\left(15.5^{\circ} \mathrm{C} / \mathrm{min}\right)$ (Table 6$)$. These combine good matrix fracture toughness, reasonable interface quality [4] and limited internal stresses. The ductile interface (Fig. 10b) suggests strong fibre-matrix interactions [31]. For the fast cooled composite $\left(93^{\circ} \mathrm{C} / \mathrm{min}\right)$ fibre pull-out and clean fibres indicate early debonding (Fig. 10c). The annealing step has little effect on delamination resistance, once again relaxation is very limited in the reinforced matrix [29], in contrast to the micro-scale samples.

\subsection{Micro-Macro relationship, Energy balance.}

Damage development during mode I delamination is complex, depending both on matrix properties and fibre/matrix interface behaviour. In a previous study the fracture energy $\mathrm{G}_{1 \mathrm{c}}$ of the flax fibre/PLLA interface was measured for the same thermal conditions using microdroplet debonding [4]. Based on these data it is possible to propose a delamination energy balance model, using the approach proposed by Dharan et al. [32]. For a UD composite with a hexagonal fibre arrangement and ignoring mode III one obtains : 
$G_{1_{\text {composite }}}=1.05 V_{f}^{0.5} G_{1 / \text { nterface }}+\left(1-1.05 V_{f}^{0.5}\right) G_{1 \text { matrice }}$

with $\quad V_{f}=\frac{\pi}{2 \sqrt{3}}\left(\frac{d}{h}\right)^{2}$

with $\mathrm{d}$ the fibre diameter and $\mathrm{h}$ the distance between fibres. However, the reinforcement used here is in mat form, a random in-plane fibre distribution. A square arrangement is therefore used for $\mathrm{G}_{\text {Icomposite }}$ of volume:

$V_{f}=\frac{\pi}{4}\left(\frac{d}{h}\right)^{2}$

Eq. 14 then becomes :

$G_{\text {Icomposite }}=1.13 V_{f}^{0.5} G_{\text {Interface }}+\left(1-1.13 V_{f}^{0.5}\right) G_{\text {Imatrix }}$

Table 7 summarizes the results for the strain energy release rates of the PLLA matrix, the flax/PLLA interface and the flax mat/PLLA biocomposite. The results for the biocomposites are compared with estimations made using Eq. (14) and (17). Two fibre arrangements are considered (hexagonal and square) and two loading modes (mode I with or without a mode III component). Cooling rates indicated by an asterisk are those for microdroplet samples.

First, it is apparent that fracture energies for matrix, interface and composite are very different (Table 7). Various authors have discussed matrix-composite toughness transfer in the past, notably Hunston [33], who distinguished between brittle matrix resins with fracture energies up to about $200 \mathrm{~J} / \mathrm{m}^{2}$, for which addition of fibres improved fracture energy, and tougher resins for which fibres reduced the toughness. This was discussed by various authors in terms of constraints on the development of crack tip plastic zones. Here the composite toughness is roughly half that of the matrix. The matrix can dissipate energy through elasto-plastic behaviour but the different tests show that the effects of thermal treatments are not simple. For example, slow cooling $\left(1.5^{\circ} \mathrm{C} / \mathrm{min}\right)$ increases the fibre-matrix interface toughness but the $\mathrm{G}_{1 \mathrm{c}}$ of the composite decreases. Annealing does not have a significant effect on mode I delamination resistance (Table 7) nor in-plane shear properties (Table 4) while at the micro scale the relaxation of internal stresses leads to a large drop in interface toughness [4]. At the composite scale the matrix properties and morphology appear to dominate those of the interface. An energy balance approach gives an indication of the trends observed but the notion of a representative volume element to describe a mat layer is open to discussion. Other 
phenomena such as friction could also be taken into account in a more complete model. The complex microstructure of the flax fibres may also contribute to cracks propagating within the outer layers of the fibre, indeed Baley et al [6] have indicated cracks developing within the flax fibres in transverse tension tests on flax composites.

\section{Conclusion}

This study presents results from a study of the behaviour of flax reinforced PLLA under inplane shear and mode I interlaminar fracture testing. These tests are sensitive to both matrix and interface, and these macro-scale results have been correlated with microdroplet interface debonding and matrix characterization measurements from a previous study.

Flax/PLLA biocomposites with no additional fibre surface treatment show similar in-plane shear properties and mode I delamination resistance values to those of glass/polyester composites. The mechanical properties measured depend strongly on the cooling rate and hence on the matrix microstructure. Slow cooling of the unreinforced polymer has been shown to develop crystalline structure, resulting in an improvement in matrix strength and Young's modulus but a drop in toughness. The in-plane shear properties and $\mathrm{G}_{\mathrm{Ic}}$ values also drop for the slowest cooling rate. The best combination of in-plane shear performance and delamination resistance is noted for an intermediate cooling rate, $\left(15.5^{\circ} \mathrm{C} / \mathrm{min}\right)$. These combine good matrix fracture toughness and reasonable interface quality [4]. A simple energy balance approach enables trends in composite fracture energy with cooling rate to be estimated, but the complexity of the natural fibre reinforcement limits quantitative modelling. Current studies are focussed on improving the properties of these materials. Increasing matrix properties, and in particular failure strain is one approach. If further improvements are to be achieved a better understanding of the fibre damage mechanisms is also needed, as the critical element in transverse loading is the cohesion of the fibre itself.

\section{References}

1. Le Duigou A, Pillin I, Bourmaud A, Davies P, and Baley C, Effect of recycling on mechanical behaviour of biocompostable flax/poly(l-lactide) composites. Composite Part A, 2008. 39(9): p. 14711478 .

2. Le Duigou A, Jouanne G, Grohens Y, Davies P, and Baley C, Life Cycle Analysis comparison between a flax/PLLA biocomposite and a traditional glass/Polyester composite. International Journal of Life Cycle Assessment, 2009. Under soumission.

3. Bodros E, Pillin I, Montrelay N, and Baley C, Could biopolymers reinforced by randomly scattered flax fibre be used in structural applications? Composites Science and Technology, 2007. 67(3-4): p. 462470.

4. Le Duigou A, Davies P, and Baley C, Interfacial bonding of flax/Poly(L-Lactide) biocomposites. Composites Science and Technology, 2009. Accepted for publication. 
5. Herrera-Franco P and Drzal L, Comparison of methods for the measurement of fibre/matrix adhesion in composites. Composites, 1992. 23(1): p. 2-27.

6. Baley C, Perrot Y, Busnel F, Guezenoc H, and Davies P, Transverse tensile behaviour of unidirectional plies reinforced with flax fibres. Materials Letters, 2006. 60(24): p. 2984-2987.

7. Romhány G, Kocsis J, and Czigány T, Tensile Fracture and Failure Behavior of Thermoplastic Starch with Unidirectional and Cross-Ply Flax Fiber Reinforcements. Macromolecular Materials and Engineering, 2003. 288(9): p. 699-707.

8. Wong S, Shanks R, and Hodzic A, Mechanical behavior and fracture thoughness of poly(lactic acid)natural fibre composites modified with hyperbranched polymers. Macromolecular Materials and Engineering, 2004. 289(5): p. 447-456.

9. Perrot Y, Influence des propriétés de la matrice sur le comportement mécanique de matériaux composites verre/polyester utilisés en construction navales de plaisance, in $\mathrm{PhD}$ Thesis (In french). 2006, Université de bretagne sud: Lorient.

10. Davies P and Cantwell W, Fracture of Glass/Polypropylene laminates : influence of cooling rate after moulding. Composites, 1994. 25(9): p. 869-877.

11. Perrin F, Bureau MN, Denault J, and Dickson JI, Mode I interlaminar crack propagation in continuous glass fiber/polypropylene composites: temperature and molding condition dependence. Composites Science and Technology, 2003. 63(5): p. 597-607.

12. ASTM-D3518, In-Plane shear response ofpolymer matrix composite materials by tensile test of a $+-45^{\circ}$ laminate. Annual Book of ASTM standarts, 1995. 14.01.

13. Whitney J, Bending-extensional coupling in laminated plate under transverse loading. J. Compos. Mater, 1969. 3: p. 20.

14. ISO-15024, Fibre-reinforced plastic composites - Determination of mode I interlaminar fracture toughness, GIC, for unidirectionally reinforced materials. 2001.

15. Thomasson J. Why are natural fibres failing to deliver on composite performance? in 17 th International conference on composite materials (ICCM). 2009. Edimburg.

16. Halpin $\mathrm{J}$ and Kardos J, The Halpin-Tsai Equations: A review. Polymer Enginneering And Science, 1976. 16(5).

17. Baley C, Analysis of the flax fibres tensile behaviour and analysis of the tensile stiffness increase. Composite Part A: Applied Science and Manufacturing, 2002. 33(7): p. 939-948.

18. Ye L, Beehag A, and Friedrich K, Mesostructural aspects of interlaminar fracture in thermoplastic composites: Is crystallinity a key? Composites Science and Technology, 1995. 53(2): p. 167-173.

19. Brunner AJ, Blackman BRK, and Davies P, A status report on delamination resistance testing of polymer-matrix composites. Engineering Fracture Mechanics, 2008. 75(9): p. 2779-2794.

20. Davies P and Brunelliere O, Effect of defects on interlaminar fracture of glass fibre-reinforced polyester composites. Journal of materials science Letters, 1993. 12(427-429).

21. Berry J, Determination of fracture surface energies by the cleavage technique. Journal of Applied Physics, 1963. 34.

22. ISO-13586, Plastics - Determination of fracture toughness $\left(\mathrm{G}_{\mathrm{IC}}\right.$ and $\left.\mathrm{K}_{\mathrm{IC}}\right)$ - Application of linear elastic fracture mechanics (LEFM). International Standards Organisation, 2000.

23. Williams J, Stress analysis of Polymers. Ellis Horwood series in engineering science, 2nd ed. 1980.

24. Ray S, Yamada K, Okamoto M, and Ueda K, Crystallization behaviour and morphology of biodegradable polylactide/layered silicate nanocomposite. Polymer, 2003. 44: p. 857-866.

25. Auras R, Harte B, and Selke S, An Overview of Polylactides as Packaging Materials. Macromolecular Bioscience, 2004. 4(9): p. 835-864.

26. Compston P, Jar P-YB, and Davies P, Matrix effect on the static and dynamic interlaminar fracture toughness of glass-fibre marine composites. Composites Part B: Engineering, 1998. 29(4): p. 505-516.

27. Pomel C, Contribution à l'étude de matériaux composites renforcés par des fibres de lin, $\mathrm{PhD}$ thesis (in French), Génie civil. 2003, Université de Nantes: Nantes.

28. Baley $\mathrm{C}$, Contribution à l'étude de matériaux composites à matrice organique renforcés par des fibres de lin- Rapport HDR. 2003, Unuiversité de Bretagne Sud: Lorient.

29. Parlevliet P, Bersee H, and Beukers A, Residual stresses in thermoplastic composites--A study of the literature--Part I: Formation of residual stresses. Composite Part A: Applied Science and Manufacturing, 2006. 37(11): p. 1847-1857.

30. Gassan J and Bledzki A, Thermal degradation of flax and jute fibers. Journal of Applied Science, 2001. 82(6): p. 1417-22.

31. Lariviere D, Krawczak P, Tiberi C, and Lucas, Interfacial properties in commingled yarn thermoplastic composites. Part II : Influence on crack initiation and propagation. Polymer Composites, 2004. 25(6).

32. Dharan C and Saghizadef H, Delamination fracture thoughness of graphite and aramid epoxy composites. Journal of engineering materials and technology, 1986. 108: p. 290-295. 
33. Hunston D, Composite interlaminar fracture: effect of matrix fracture energy. Compos. Technol. Rev, 1984. 6: p. 176-180. 


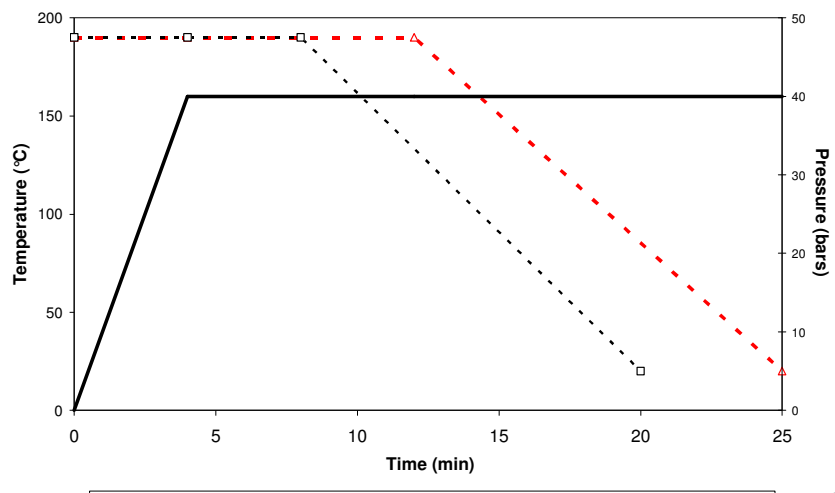

$-\Delta^{*} \quad$ Temperature In-plane shear $\left({ }^{\circ} \mathrm{C}\right) \cdot \square \cdot$ Temperature Mode I — presure (bars)

Fig. 1 Film stacking manufacturing cycle for in-plane shear and mode I specimens with water cooling $\left(\sim 15.5^{\circ} \mathrm{C} / \mathrm{min}\right)$

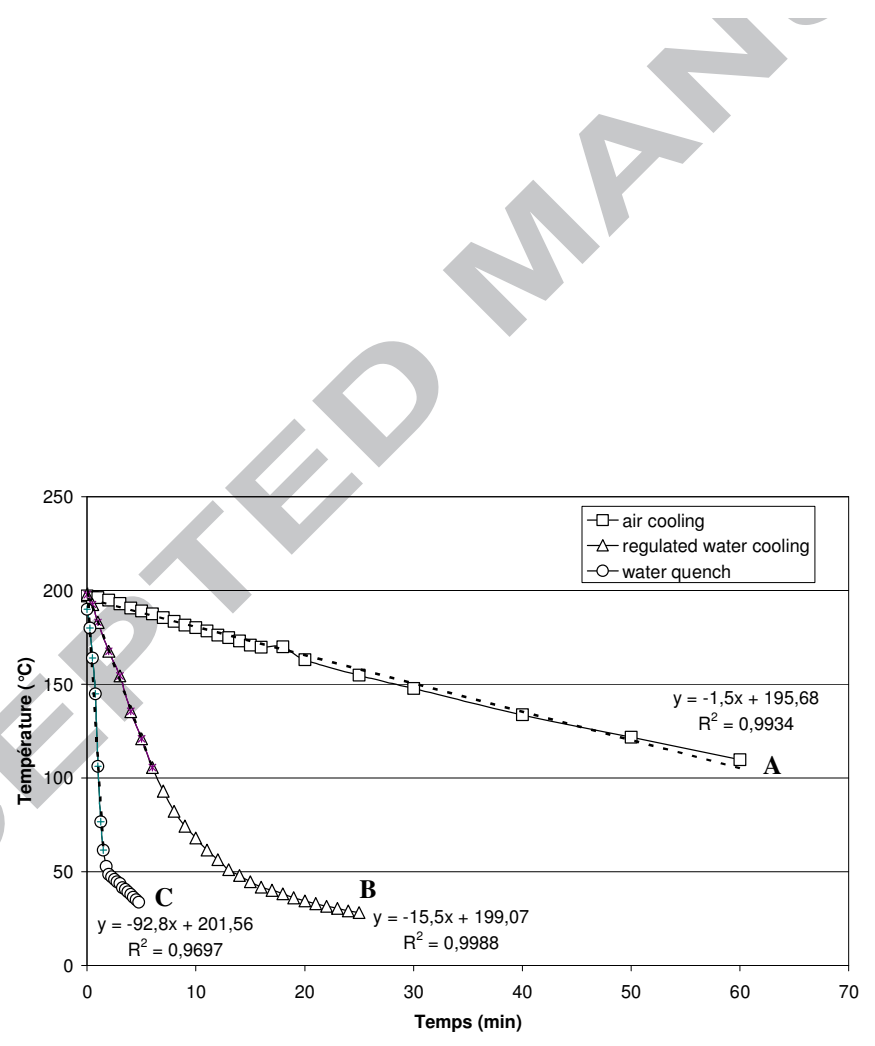

Fig. 2 Cooling kinetics for biocomposites 


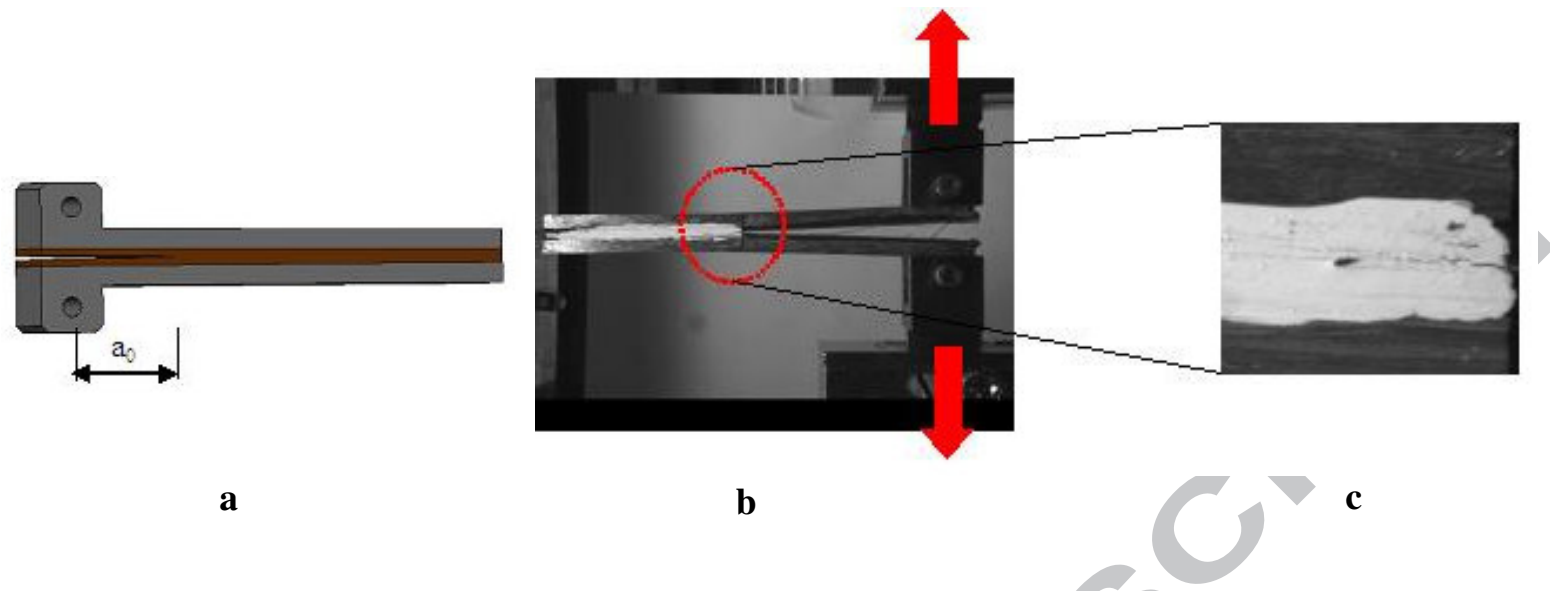

Fig. 3 a). Delamination sample. b)- Delamination test fixture. c)- example of crack tip image recorded
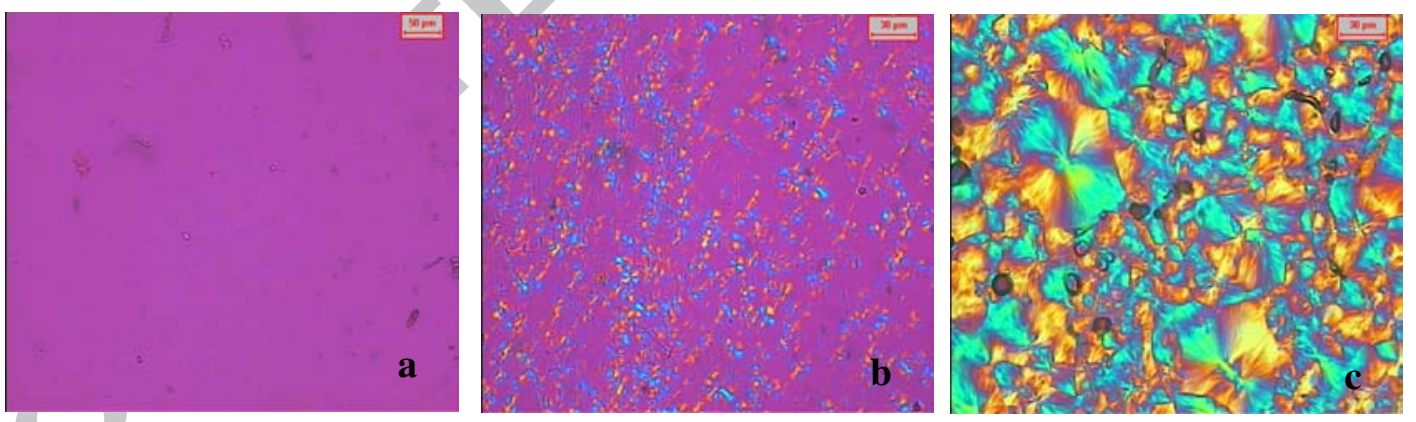

Fig. 4a Matrix morphology of PLLA cooled at $93^{\circ} \mathrm{C} / \mathrm{min}$. b at $15.5^{\circ} \mathrm{C} / \mathrm{min}$. c $1.5^{\circ} \mathrm{C} / \mathrm{min}$ 


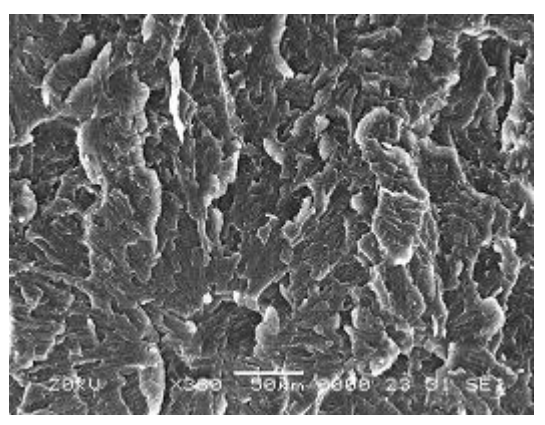

$\mathbf{a}$

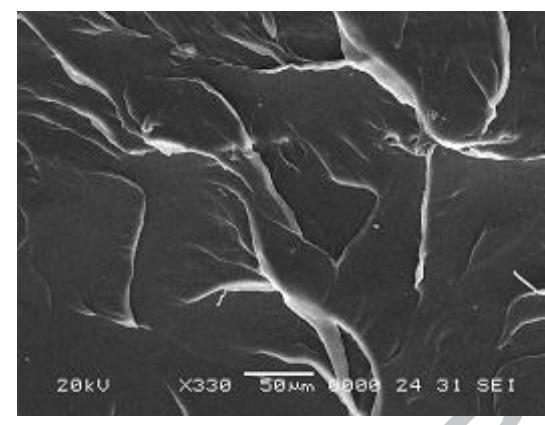

b

Fig. 5a SEM photography of $\mathrm{K}_{1 \mathrm{c}}$ specimen fracture surface, $1.5^{\circ} \mathrm{C} / \mathrm{min}$ cooling rate. $\mathbf{b} 15.5^{\circ} \mathrm{C} / \mathrm{min}$ cooling rate

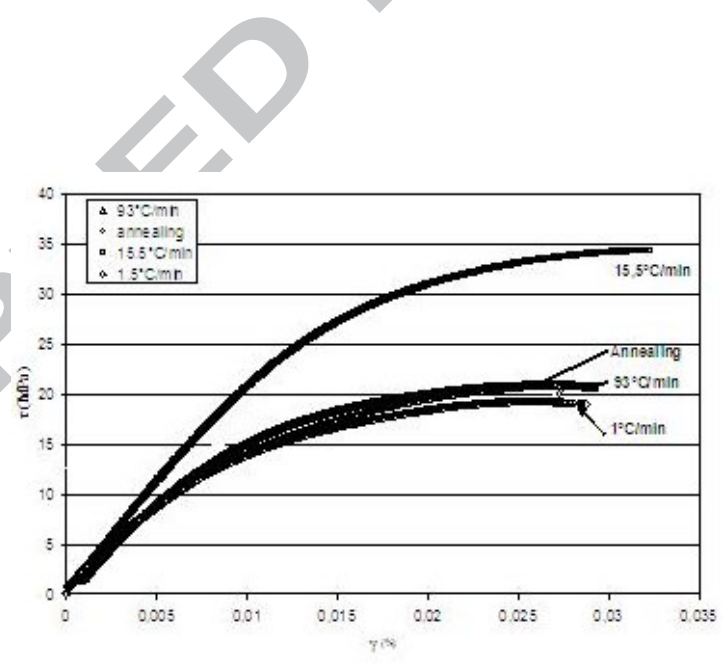

Fig. 6 In-plane shear stress-strain plots 


\section{ACCEPTED MANUSCRIPT}

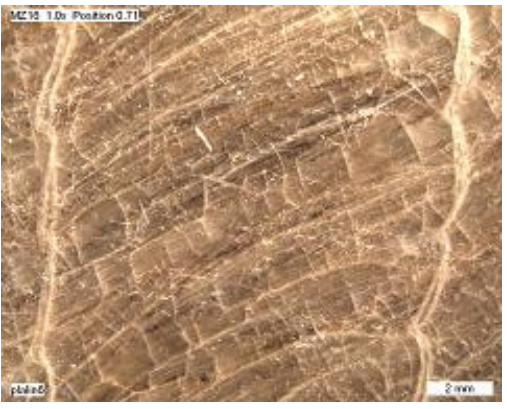

$\mathbf{a}$

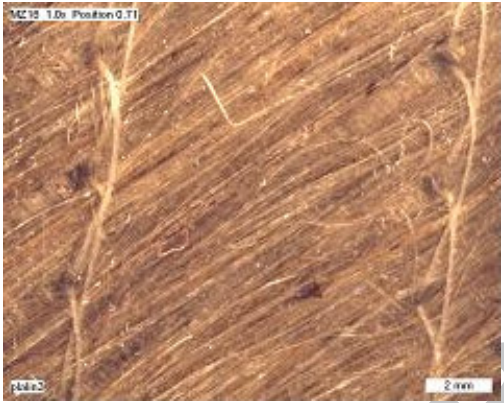

b

Fig. 7a Surface of biocomposite specimen after cooling at $1.5^{\circ} \mathrm{C} / \mathrm{min}$. b. at $15.5^{\circ} \mathrm{C} / \mathrm{min}$

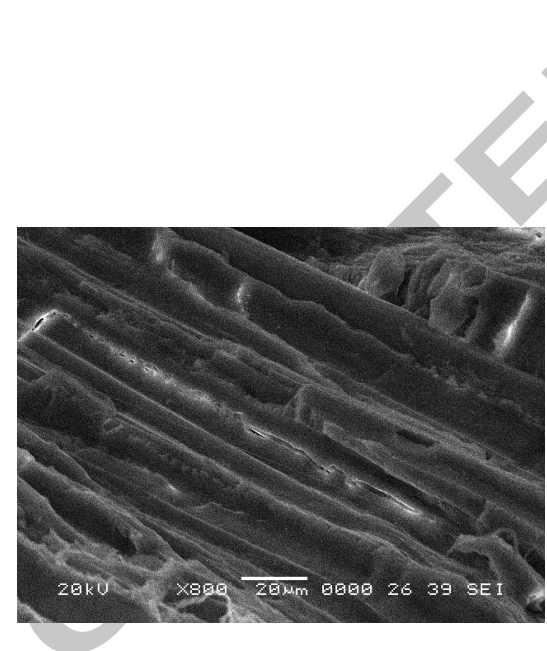

a

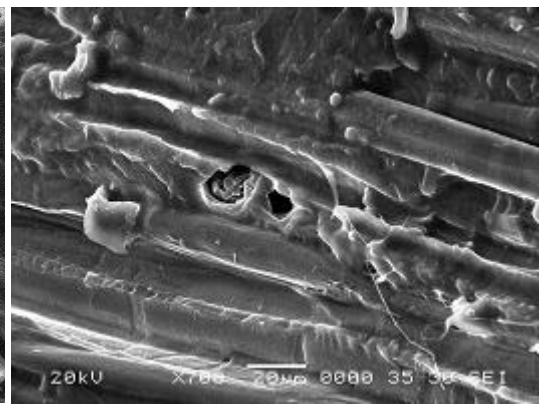

b

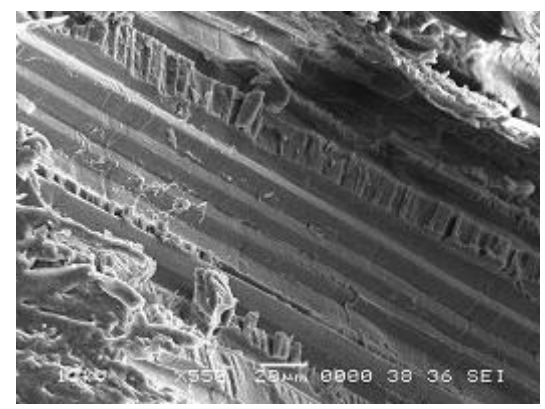

c

Fig. 8a SEM photography of fracture surface of sample cooled at $1.5^{\circ} \mathrm{C} / \mathrm{min} . \mathbf{b} 15.5^{\circ} \mathrm{C} / \mathrm{min}$. $\mathbf{c} 93^{\circ} \mathrm{C} / \mathrm{min}$. 


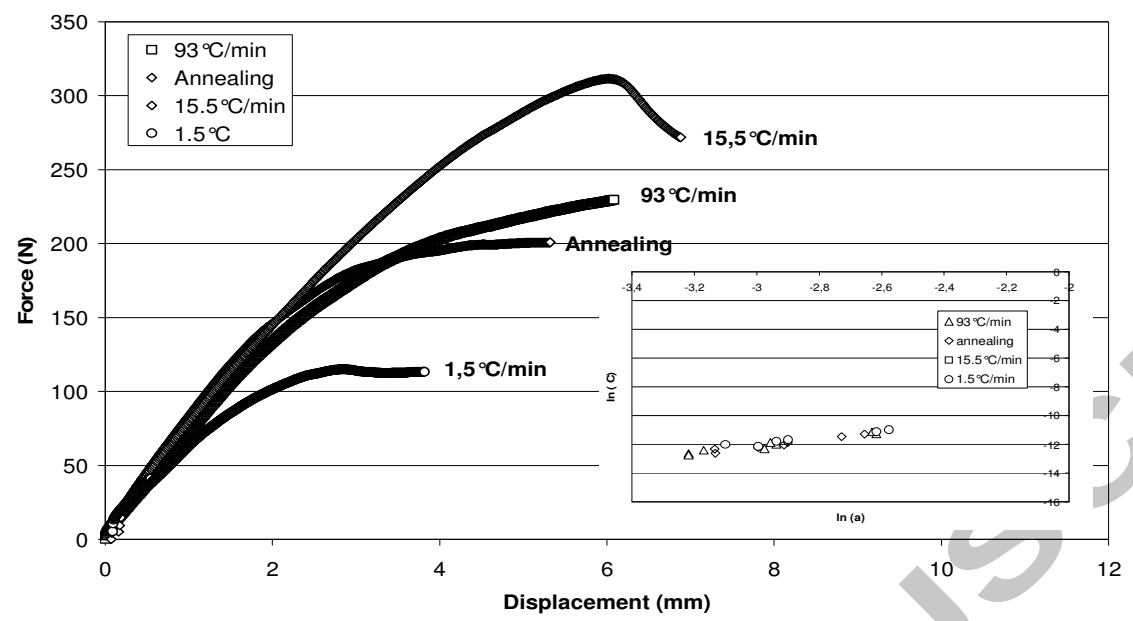

Fig. 9 Force versus opening displacement, mode $\mathrm{I}$, for specimens with $\mathrm{a}_{\mathrm{o}} \approx 70 \mathrm{~mm}$ with different thermal manufacturing conditions. Insert: Values of compliance versus initial crack length, all specimens

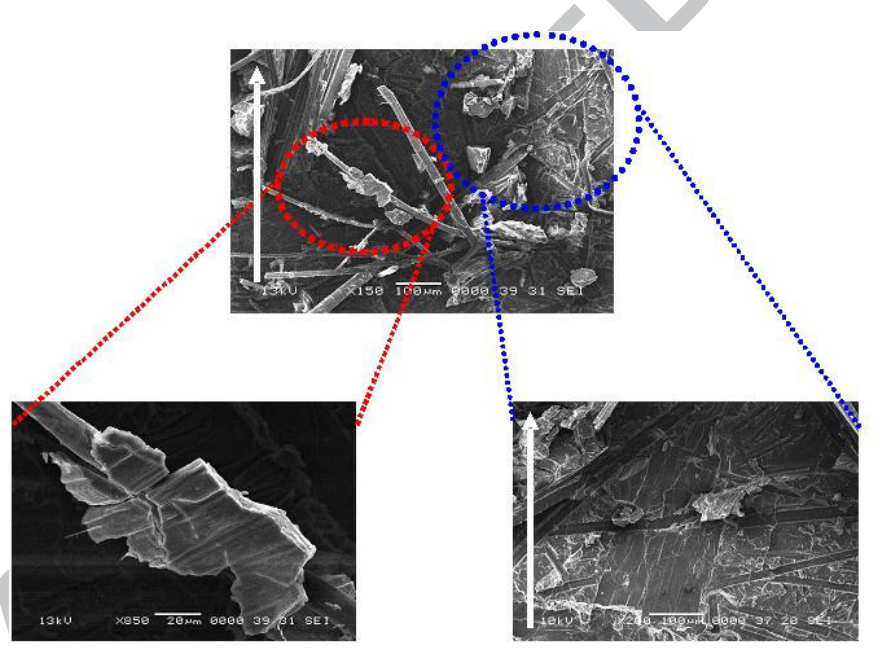

a
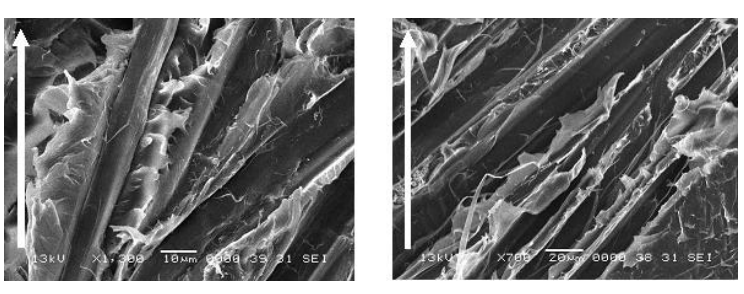

b
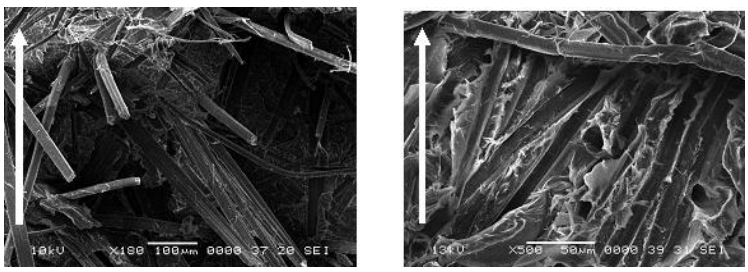

c

Fig. 10 SEM photo of slow cooled mode I specimen a) $1.5^{\circ} \mathrm{C} / \mathrm{min}$., white arrows indicate delamination direction.

b) Sample cooled at $15.5^{\circ} \mathrm{C}$ c) fast cooled $\left(93^{\circ} \mathrm{C} / \mathrm{min}\right)$ mode I fracture surfaces 


\section{Table Captions}

Table 1 Thermal properties (DSC) for different cooling rates

Table 2 Mechanical properties in tension and shear of PLLA for different thermal conditions [4]. Mean values \pm standard deviations

Table 3 Critical stress intensity factor $\left(\mathrm{K}_{\mathrm{Ic}}\right)$, and fracture energy $\left(\mathrm{G}_{\mathrm{Ic}}\right)$ of PLLA for different manufacturing conditions. Mean values \pm standard deviations

Table 4 In-plane shear properties of Flax/PLLA bio-composite for different thermal conditions Mean values \pm standard deviations

Table 5 Measured and estimated in-plane shear modulus of Flax/PLLA biocomposites.

Table 6 Critical strain energy release rates at initiation $\mathrm{G}_{1 \mathrm{c}}$. Mean values \pm standard deviations

Table 7 Energy balance for mode I cracking 
Table 1 Thermal properties (DSC) for different cooling rates

\begin{tabular}{|l|l|l|l|l|}
\hline \multirow{3}{*}{ Material } & $\begin{array}{l}\text { Thermal } \\
\text { treatment }\end{array}$ & $\Delta \mathrm{H}_{\mathrm{c}}(\mathrm{J} / \mathrm{g})$ & $\Delta \mathrm{H}_{\mathrm{m}}(\mathrm{J} / \mathrm{g})$ & $\begin{array}{l}\text { Degree of } \\
\text { crystallinity }(\%)\end{array}$ \\
\hline \multirow{5}{*}{ PLLA } & $93^{\circ} \mathrm{C} / \mathrm{min}$ & 25.8 & 26 & - \\
\cline { 2 - 6 } & Annealing & 24.9 & 25.3 & - \\
\cline { 2 - 6 } & $15.5^{\circ} \mathrm{C} / \mathrm{min}$ & 23 & 26.7 & 8 \\
\cline { 2 - 5 } & $1.5^{\circ} \mathrm{C} / \mathrm{min}$ & 1.6 & 37.7 & 33 \\
\hline
\end{tabular}


Table 2 Mechanical properties and their standard deviation in tension and shear of PLLA for different thermal conditions [4]

\begin{tabular}{|c|c|c|c|c|c|c|}
\hline \multirow[b]{2}{*}{ Material } & \multirow[b]{2}{*}{ treatment } & \multicolumn{3}{|l|}{ Tension } & \multicolumn{2}{|l|}{ Shear } \\
\hline & & $\begin{array}{l}\mathrm{E} \\
(\mathrm{MPa})\end{array}$ & $\begin{array}{l}\sigma_{\mathrm{r}} \\
(\mathrm{MPa})\end{array}$ & $\begin{array}{c}\varepsilon_{\mathrm{r}} \\
\%\end{array}$ & $\mathrm{G}_{12}(\mathrm{MPa})$ & $\tau_{12}(\mathrm{MPa})$ \\
\hline \multirow{4}{*}{ PLLA } & $93^{\circ} \mathrm{C} / \mathrm{min}$ & $\begin{array}{l}3029 \pm \\
410\end{array}$ & $56 \pm 1$ & $1.7 \pm 0.3$ & $1303 \pm 476$ & $33 \pm 0.6$ \\
\hline & Annealing & $\begin{array}{l}3394 \pm \\
149\end{array}$ & $58.3 \pm 3$ & $1.8 \pm 0.2$ & $1463 \pm 120$ & $33.7 \pm 1.7$ \\
\hline & $15.5^{\circ} \mathrm{C} / \mathrm{min}$ & $\begin{array}{l}3743 \pm \\
368\end{array}$ & $60.9 \pm 3.2$ & $2.2 \pm 0.1$ & $1609 \pm 144$ & $35.2 \pm 1.8$ \\
\hline & $1.5^{\circ} \mathrm{C} / \mathrm{min}$ & $\begin{array}{l}4003 \pm \\
410\end{array}$ & $64.4 \pm 1$ & $0.6 \pm 0.2$ & $1743 \pm 176$ & $37.8 \pm 3.3$ \\
\hline
\end{tabular}


Table 3 Critical stress intensity factor $\left(\mathrm{K}_{\mathrm{Ic}}\right)$, fracture energy $\left(\mathrm{G}_{\mathrm{Ic}}\right)$ and their standard deviation of PLLA for different manufacturing conditions.

\begin{tabular}{|l|l|l|l|}
\hline \multirow{2}{*}{ Material } & Thermal treatment & $\mathrm{K}_{1 \mathrm{c}}\left(\mathrm{MPa} \cdot \mathrm{m}^{1 / 2}\right)$ & $\mathrm{G}_{1 \mathrm{c}}\left(\mathrm{J} / \mathrm{m}^{2}\right)$ \\
\hline \multirow{3}{*}{ PLLA } & $93^{\circ} \mathrm{C} / \mathrm{min}$ & $1.66 \pm 0.28$ & $433 \pm 73$ \\
\cline { 2 - 4 } & Annealing & $1.96 \pm 0.30$ & $512 \pm 79$ \\
\cline { 2 - 4 } & $15.5^{\circ} \mathrm{C} / \mathrm{min}$ & $2.08 \pm 0.34$ & $544 \pm 90$ \\
\cline { 2 - 4 } & $1.5^{\circ} \mathrm{C} / \mathrm{min}$ & $0.63 \pm 0.02$ & $165 \pm 49$ \\
\hline
\end{tabular}


Table 4 In-plane shear properties and their standard deviation of Flax/PLLA bio-composite for different thermal conditions

\begin{tabular}{|l|l|l|l|l|l|}
\hline \multirow{2}{*}{ Material } & \multicolumn{2}{l}{$\begin{array}{l}\text { Cooling rate } \\
\left({ }^{\circ} \mathrm{C} / \mathrm{min}\right)\end{array}$} & \multicolumn{2}{l|}{ Composite } & \multicolumn{2}{l|}{ PLLA } \\
\cline { 2 - 6 } & $\mathrm{G}_{12}(\mathrm{MPa})$ & $\tau_{12}(\mathrm{MPa})$ & $\mathrm{G}_{12}(\mathrm{MPa})$ & $\tau_{12}(\mathrm{MPa})$ \\
\hline \multirow{3}{*}{ Flax/PLLA } & 93 & $1989 \pm 159$ & $22.6 \pm 3.1$ & $1303 \pm 476$ & $33 \pm 0.6$ \\
\cline { 2 - 7 } & annealing & $1972 \pm 89$ & $21.1 \pm 1.4$ & $1463 \pm 120$ & $33.7 \pm 1.7$ \\
\cline { 2 - 7 } & 15.5 & $2308 \pm 74$ & $33.9 \pm 2.1$ & $1609 \pm 144$ & $35.2 \pm 1.8$ \\
\cline { 2 - 7 } & 1.5 & $1776 \pm 252$ & $18.5 \pm 1.1$ & $1743 \pm 176$ & $37.8 \pm 3.3$ \\
\hline
\end{tabular}


Table 5 Measured and estimated in-plane shear modulus of Flax/PLLA biocomposites.

\begin{tabular}{|l|l|l|l|l|}
\hline \multirow{4}{*}{ Material } & $\begin{array}{l}\text { Cooling rate } \\
\left({ }^{\circ} \mathrm{C} / \mathrm{min}\right)\end{array}$ & $\begin{array}{l}\mathrm{G}_{12} \text { measured } \\
(\mathrm{MPa})\end{array}$ & $\begin{array}{l}\mathrm{G}_{12} \text { calculated } \\
\text { with Eq. 5 } \\
(\mathrm{MPa})\end{array}$ & Difference $\%)$ \\
\hline \multirow{4}{*}{ Flax/PLLA } & 93 & $1989 \pm 159$ & 1704 & -14.4 \\
\cline { 2 - 5 } & annealed & $1972 \pm 89$ & 1859 & -5.8 \\
\cline { 2 - 5 } & 15.5 & $2308 \pm 74$ & 1994 & -13.7 \\
\cline { 2 - 5 } & 1.5 & $1776 \pm 252$ & 2115 & +19.1 \\
\hline
\end{tabular}


Table 6 Critical strain energy release rate and their standard deviation at initiation $\mathrm{G}_{1 \mathrm{c}}$

\begin{tabular}{|l|l|l|l|}
\hline Treatment & $\mathrm{n}$ & $\mathrm{G}_{\mathrm{Ic}, \text { onset }}\left(\mathrm{J} / \mathrm{m}^{2}\right)$ & $\begin{array}{l}\text { Coefficient of } \\
\text { variation }(\%)\end{array}$ \\
\hline $93^{\circ} \mathrm{C} / \mathrm{min}$ & 2.43 & $191 \pm 58$ & 30 \\
\hline Annealing & 2.55 & $184 \pm 67$ & 36 \\
\hline $15.6^{\circ} \mathrm{C} / \mathrm{min}$ & 2.29 & $323 \pm 43$ & 13 \\
\hline $1.5^{\circ} \mathrm{C} / \mathrm{min}$ & 2.15 & $65 \pm 15$ & 24 \\
\hline
\end{tabular}




\begin{tabular}{|c|c|c|c|c|c|c|c|}
\hline $\begin{array}{l}\text { Thermal } \\
\text { treatment }\end{array}$ & $\begin{array}{l}\mathrm{G}_{1 \mathrm{c}} \text { matrix } \\
\left(\mathrm{J} / \mathrm{m}^{2}\right)\end{array}$ & $\begin{array}{l}\mathrm{G}_{1 \mathrm{c}} \\
\text { interface } \\
\left(\mathrm{J} / \mathrm{m}^{2}\right) \\
{[4]}\end{array}$ & $\begin{array}{l}\mathrm{G}_{1 \mathrm{c}} \\
\text { composite } \\
\text { initiation } \\
\text { measured } \\
\left(\mathrm{J} / \mathrm{m}^{2}\right)\end{array}$ & $\begin{array}{l}\mathrm{G}_{1 \mathrm{c}} \\
\text { calculated } \\
\text { composite } \\
\text { hexagonal } \\
(\text { Eq. 14) }\end{array}$ & $\begin{array}{l}\text { Difference } \\
\text { (\%) }\end{array}$ & $\begin{array}{l}\mathrm{G}_{1 \mathrm{c}} \\
\text { calculated } \\
\text { composite } \\
\text { square } \\
(\text { Eq.17) }\end{array}$ & $\begin{array}{l}\text { Difference } \\
(\%)\end{array}$ \\
\hline $\begin{array}{l}93^{\circ} \mathrm{C} / \mathrm{min} \\
\text { or air* }\end{array}$ & $433 \pm 73$ & $29 \pm 17$ & $191 \pm 58$ & 216 & +13 & 200 & +5 \\
\hline Annealing & $512 \pm 79$ & $13 \pm 2$ & $184 \pm 67$ & 245 & +33 & 225 & +22 \\
\hline $\begin{array}{l}15.6^{\circ} \mathrm{C} / \mathrm{min} \\
\text { or } \\
10^{\circ} \mathrm{C} / \mathrm{min}^{*}\end{array}$ & $544 \pm 90$ & 33 & $323 \pm 43$ & 270 & -16 & 250 & -33 \\
\hline $\begin{array}{l}1.5^{\circ} \mathrm{C} / \mathrm{min} \\
\text { or } \\
1^{\circ} \mathrm{C} / \mathrm{min} *\end{array}$ & $165=$ & $41 \pm 17$ & $65 \pm 15$ & 99 & +53 & 94 & +45 \\
\hline
\end{tabular}

Table 7 Energy balance for mode I cracking 